\title{
Case: Ship of Hope in a Valley of Woes
}

BalaBhaskaran*

Director, Incube Ventures Pvt. Ltd., Ahmedabad, India.

\begin{abstract}
The case is about the pioneering and innovative work done by an NGO called "Centre for North-East Studies (C-NES)" in creating health-care delivery system to the 3 million people living in the 2500 island villages in the Brahmaputra river. The Govt. of Assam could not reach these rural people due to poor transport logistics. For the first time, Sanjoy Hazarika, a journalist and Managing Trustee of C-NES came up with the idea of boat-clinics in 2005. The case traces the history and evolution of this initiative and explores the challenges being faced by the entity in achieving longterm sustainability.
\end{abstract}

Keywords: Health-care Delivery System, Inclusive development, Public-Private-Partnership, Sustainable Development, Women Empowerment

\section{Introduction}

"At 2.30 pm on a warm afternoon on April 25, 2005, at Maijanghat,Dibrugarh1, the engine of Akha2, the boat of hope, coughed into life with a surge of grey-blue smoke( the exhaust had not been fixed) that filled the engine room and sent every one into burst of coughing. There were smiles, a little applause, I shook Gurung's3 hand, having placed a ten rupee note for good luck on top of the engine. The mechanic prayed as did some of the boat makers from Dholla4 who have put it into such good shape as they lit the dhoop5. Sanjay Sharma too had placed a Rs. 20 note on the engine, someone else chipped in with a one rupee coin. The beginning of a new dream, the fulfillment or near-fulfillment of a concept that we launched last year after winning the World Bank award for innovative ideas that could transform rural society."

Excerpts from an e-mail of Sanjoy Hazarika, April 26, 20056

Thus began a new chapter in the history of a people who had not known modern medical facilities. The "boat-clinic" was destined to become a major part of their life in the near future. There were 2500 islands in the mighty river Brahmaputra and these were inhabited by almost 3 million people, most of them untouched by outside civilization. The power of the river Brahmaputra showed up in a hostile geographic terrain leaving little scope for interaction with the outside world. The people in these islands lived an isolated life with little interactions even for basic necessities like emergency care, education etc. It is into this world that Sanjoy Hazarika and associates were, with fervent prayers in their hearts, chugging the steamer called "Akha"(meaning Hope in Assamese language, 'Asha' in many other Indian languages). While the initiative was brave and innovative, it needed much more than the fervent prayers of the small group to reach its destination through the wild and choppy waters of Brahmaputra.

\section{Brahmaputra Valley and the Developmental Deficit}

River Brahmaputra with its origin in Tibet, flows through southern Tibet, crosses the Himalayas in 
great gorges to enter India's Arunachal Pradesh. Then it flows in a south-westerly direction through the Brahmaputra Valley (also known as the Assam Valley) before turning south into the vast Ganges Delta and the rivers of Padma and Meghna in Bangladesh and finally emptying into the Bay of Bengal. The Brahmaputra River is $3,848 \mathrm{kms}$ long; it has an average depth of 38 meters (124 feet) and the maximum observed depth is 120 meters (380 feet). The river is prone to catastrophic flooding in spring when the Himalyan snows melt. The average discharge of the river is observed to be 19,300 cubic meters per second (680,000 cubic feet per second or cu.sec) while the maximum discharge during floods is found to be 100,000 cubic meters per second $(3,500,000 \mathrm{cu} . \mathrm{sec})$. With its flow, the river transports suspended sediment load of about 1.84 billion tons per year which is the highest for any river in the world. Most of the islands of Brahmaputra are prone to submerging or even to complete destruction during the floods, which are perennial, and through the natural process of channel-migration resulting in vast changes in the topography. Over the generations the island dwellers have learnt to adapt and live with the river. Brahmaputra is navigable for major portion of its length ${ }^{7}$.

Once in India, Brahmaputra makes rapid descent from its original height in Tibet into the valley where it is joined by other rivers, Dibang and Lohit and further down by rivers Sonitpur and Kameng. In the plains Brahmaputra is very wide - as wide as $10 \mathrm{kms}$ in certain parts. Within the Indian state of Assam Brahmaputra traverses $891 \mathrm{kms}$ literally slicing the state into northern and southern parts. Between Dibrugarh and Lakhimpur districts of Assam, Brahmaputra divides into two channels - the upper or northern Kherkutia channel and the lower or southern Brahmaputra channel; $100 \mathrm{kms}$ downstream these channels unite again into a single river. The land between the two channels is the Majuli Island, one of the biggest river-islands in the world. Floods were a common occurrence in Brahmaputra, during monsoon due to rains as also during spring due to melting of Himalayan snow.

Along the $891 \mathrm{kms}$ stretch of Brahmaputra, from Sadiya to Dhubri, there are 2500 island-villages inhabited by people with diverse ethnic and cultural background. The upper stretches of the river are predominantly inhabited by Mising communities who live on houses built on stilts. Bodos, Assamese, Bengali and Bihari communities are the other settlers in these islands where the main occupation consists of agriculture and dairy farming. Downstream, from Sonitpur to Dhubri Muslims are the dominant inhabitants.

All these made the development of transport and logistics infrastructure in the valley extremely difficult. In the post-1947 period the problem got aggravated with the emergence of international borders and limited access to the north eastern region of India from the mainland through the Siliguri Corridor (also known as chicken'sneck). The state of Assam, which covers most of the Brahmaputra valley, had a population of 31 million in 2011. Of this nearly 3 million were residing in the 2500 river-islands situated in Brahmaputra. Economic and social development of the region was handicapped by the poor transport and logistics infrastructure of the region which in turn was caused by the peculiar geography and history of the region. Economists and social anthropologists have observed that societies that had lesser interaction with outside world due to their peculiar geography - often called economic geography - were slower in development. If this had continued for long period of time such societies had to suffer from, what economists call, differential development ${ }^{8}$.

\section{The Concept}

Sanjoy Hazarika - a journalist, writer, movie-maker and social worker all rolled into one - came up with the idea that the rivers of Assam needed to be perceived and harnessed as resources and allies rather than being perceived as destructive forces. He had travelled the entire length of Brahmaputra, from Tibet to the Bay of Bengal, while creating documentaries on Brahmaputra; one of them titled A River's Story: the Quest for the Brahmaputra. Hazarika was born in Shillong and had spent early part of his life in Assam; these ensued that he had first-hand knowledge about the trauma of life in that area. Sanjoy Hazarika, conceived a proposal to develop a well-designed but locally built country boat, adapted to low-draft and quick-movement, to carry 
medical teams - government and/or private - and life saving medical supplies as well as other essential and emergency goods. He felt such boats would serve as mobile clinics in situations of flood as also vehicles of social development in normal times 9 . Sanjoy Hazarika had also spelt out that in the long run a fleet of such boats would be far more effective than conventional means in the development process of river-dependent communities of the Brahmaputra valley.

"..........such boats could carry tools for improved sanitation and hygiene, both in times of flood and in the dry season, including oral re-hydration kits, teaching tools for children and young adults on these issues, seeking to mobilize human resources in the villages along the rivers in a campaign for change and better health. These designs would be designed to carry such equipment and facilities and personnel. In addition they would carry safety equipment (life-jackets etc.) which are hardly seen in country boats in Assam. During the dry season, the boats could be used also as communication/education centres by conducting workshops on shore and on the vessels with the assistance of prominent scholars and environmentalists to interact with and the partner river-dependent communities to listen to their views, record their voices and also explain the ecosystem of the region and the natural wealth of the rivers. We propose the design and structure of one such boat to show that the unique resources of the region can be tapped for innovative and sustainable change through Boats of Hope."

Extract from the proposal that went into the World Bank Development Marketplace200 ${ }^{10}$.

\section{Long-term Objectives}

Sanjoy Hazarika envisaged a definite set of long-term objectives far beyond just providing medical help in times of crisis created by floods. The initial proposal itself had this to say:

"Through the process of designing and building such a boat, we would seek to encourage changes in government policies to develop a fleet of ships which can, not just reach the stranded at times of flood but also become part of macro and micro level planning and implementation - these are practical ways to close gaps in rural needs.

Thus, a fleet of privately owned vessels, licensed by panchayats $^{11}$ and local government bodies, based on the prototype, can help the local low-cost transportation of the people and goods (inland water transport is far more economical than other modes of surface transport at the prevailing technology and price levels); it can strengthen the local economy and tackle poverty by generating jobs, reviving the haat and ghat culture ${ }^{12}$ (markets related to the river-ports), renew skills and build new perspectives. Above all, through the innovative strategy outlined above, it can help meet gaps in rural service especially in rural health, sanitation and education - the latter in broader sense through communication ( films, street plays and other presentations) - and involving village-level groups in developing a stake in their own future, instead of being dependent on tardy official responses.

This would be people-friendly approach, which can help meet basic needs in health care and sanitation and reach those in difficulty at times of flood and erosion. These ships can carry health care workers and relief materials but also ideas - in the form of resource persons who work with rural communities in understanding their problems, recording their voices and ensuring these reach policymakers at all levels. In the process those at the village level can also become trainers who can reach out directly to other rural groups and to officials shaping policy and overseeing implementation."

\section{Plans}

This idea was developed into a proposal by Centre for North East Studies (C-NES) of which Sanjoy Hazarika was the Managing Trustee, and submitted to the World Bank as a competitive entry to the Bank's "Development Marketplace 2004" which supported innovative projects that envisaged significant impact on rural development. The proposal was titled 
"Ship of Hope in a Valley of Flood." The first round of eliminations brought down the number of competitors from 1500 to 50; 20 from among these - Ship of Hope $(\mathrm{SOH})$ and nineteen others - were selected for the Bank's support. SOH was awarded US\$ 20,000 to design and implement the idea in June 2004.

Initially the project envisaged active association with Rastriya Grameen Vikas Nidhi which had a fine trackrecord of partnerships in rural development. CNES planned to take help from Inland Waterways Authority of India, Central Inland Water Transport Corporation, Inland Water transport Department of Assam, Owners and builders of country boats in Assam etc. A traditional centre of Assam's boat builders was at a place called Dholla in Tisukhia District. Sanjoy Hazarika planned to have his boat built at this place, possibly with external support in design up-gradation and boat building techniques. As the project progressed C-NES found strong support from the MIT design team at Cambridge, Massachusetts consisting of Dinesh Balachandran and Anand Sivaraman as well as from Dr Hari Nair, an independent hydro engineering consultant from Boston to the primary work being done by the country-boat craftsmen of Assam ${ }^{13}$. Association of India Development (AID) and Assamese community members in the US also came in with active help and cooperation.

"Akha", the ship of hope, ventured out into the deep waters of Brahmaputra, its maiden trip, on $13^{\text {th }}$ May 2005, in less than a year of the World Bank award. Akha was meant to be the prototype; to make a difference in the life of 3 million target population a fleet of boats/ ships would be required. This would need enormous resources which even the state government would find difficult to mobilize. So C-NES decided to explore a strategy of seeking support from a variety of sources ${ }^{14}$.

- Support/collaboration from private industries in Assam (Tea, Oil\& Gas) for funding or other support to operate and maintain the ship for the next three years.

- Coordination and collaboration of the district administration in three vital areas
- Meeting the fuel costs

- Coordinating a weekly tour program and inform the villagers a day ahead of the ships arrival and ensuring safety.

- Providing the medical team - doctors, paramedics and medicines.

- Cooperation with Red Cross and medical fraternity that would enable doctors, health workers and medicines to move around the target areas.

- Explore the prospect of charging a nominal fee for treatment in normal times; in times of crisis there would be no question of charging anything. CNES had received interest from ICICI insurance company for covering the entire target population under health insurance scheme at a premium of Rs 130 (US\$ 4) per person per annum.

- Network with leading institutions like IIT, Netralaya etc to upgrade Akha's capabilities and to explore new vistas of operation.

- Support from medical/pharma companies for equipments and medicines.

- Develop teams of trainers to perform functions of para-medic and para-vet in the target area.

- In lean season lease out the boat for purposes of research and documentation to agencies like National Geographic, Doordarshan etc.

- Catalyze the development of a network of inland transport system for movement of people and goods across the valley and beyond.

\section{AKHA - The Pilot Project}

The launch of Akha was a more like a pilot project: a brilliant idea being tested in an extremely challenging environment with nil-to-limited resources. The project was being run as a Public-Private-Partnership (PPP) between the state government of Assam and C-NES. The project solicited support, help and donations from a variety of donors. UNICEF and National Rural Health Mission (NHRM) of the Govt. of Assam became actively associated with the project as it unfolded. "Akha" was the first boat-clinic which started working in the district of Dibrugarh, in the upper Assam. 
A boat-clinic, as it came to be known, normally had a district community organizer, two doctors, one general-nurse-cum-midwife, one pharmacist, one laboratory technician, two auxiliary nurse midwives, three community workers and four crew members. This made the manpower strength of 15 persons on board a boat-clinic. Each boat, 65 feet long and 10 feet wide, had space for one out-patient department, a doctor's cabin, a medicine chest, laboratory, kitchen, toilet and general store. A generator and a 200 litre water tank were installed on the boat. The boat was powered by a $120 \mathrm{hp}$ Tata engine ${ }^{15}$. The plan was to have a boatclinic each to a district. The target was to visit each nodal village once in a week, camp for a day and cover the health care needs of a target population of 15,000 to 20,000 .

The challenges the boat-clinics and the project faced were many. The limitation of resources in terms of boat-clinics, supplies and trained manpower was the first. Most of the people volunteered were young: medical graduates and paramedics. They were an inspired lot with high level of desire and commitment to serve the underprivileged. There was the problem of security due to the insurgency prevailing in the state. During the monsoon it was really tough to reach the islands; there were instances when a boat-clinic got stranded in the swelled-up river. It was equally tough during summers when the water-level receded, forcing the boat to anchor at distances of 5 or even 10 kilometers away from the destination. The staff needed to trudge the distance through wet clay and shallow water carrying loads of medicines and equipment.

\section{Operations and Progress}

The success of Akha in the initial years brought conviction and confidence among the prime partners. Govt of Assam was keen to upscale the program significantly. On $1^{\text {st }}$ February 2008 an MOU (Memorandum of Understanding) was signed under the Public Private Partnership (PPP) mode between C-NES and NHRM to cover the districts of Dhemaji, Tinsukia, Morigaon, Dhubri and Dibrugarh. As per the MOU, C-NES was to bring in the boats while NHRM was obliged to cover the operating costs. The first boat Akha had come from
Sanjoy Hazarika with the support of World Bank. Swaminathan S. Ankalesariya Aiyar, noted economist, journalist and philanthropist, came forward to donate boats similar to Akha. Over the next few years Mr. Aiyar donated five boats; each boat was named after one of his family members ${ }^{16}$. During 2009 and 2010 C-NES and NRHM decided to further upscale the activities and more boats were added. Indian Oil Corporation sponsored SB Nahor for use in Jorhat district. Numaligarh refinery Ltd sponsored SB Numali for use in Sonitpur district. Oil India Ltd also sponsored a boat. All these boats were built at Maijan Ghat, Dibrugarh strictly in accordance with the technical specifications created by C-NES. By the close of 2012 there were 15 boats covering all the 13 districts (Dhubri, Barpeta, Goalpara, Bongaigaon, Nalbari, Kamrup, Morigaon, Sonitpur, Lakhimpur, Dhemaji, Jorhat, Dibrugarh and Tinsukia) which needed to be covered under the project ${ }^{17}$. The project had 235 dedicated staff organized in 15 units to cover the entire target population.

The boat-clinics had two modes of operation. Where specially designed boats like Akha were available, the team went on trips of 4 to 6 days at a stretch conducting one or two camps every day. Where specially designed boats were not available, country boats were hired and re-fitted to provide basic provisions including an OPD (Out Patient Department) and a cabin for ANC (Ante-Natal-Care) checkup. Generally each district was assigned to a unit which had a district office which functioned as its nerve-centre. The district was headed by a District Program Officer (DPO) who coordinated with district health society and the targeted communities as well as Medical Officers and supporting clinical staff. The DPO is monitored and guided by the Program Management Unit (PMU) which operated from Delhi and Guwahati.

The main thrust of the program was to provide healthcare services to the mother and the child apart from curative and preventive healthcare. In rural Assam it was almost impossible for pregnant women to get regular medical check-ups. Going to a doctor meant travelling in boats to cross a river, very often swollen and with choppy waters, and then trudging through dense forest on foot for kilometers. So most often 
pregnant women avoided such adventures and simply resigned to their destiny. This was one of the reasons for the high Maternal Mortality Rate (MMR or maternal deaths per 100,000 live births) of 390 for Assam against the national average of 212 births. This was among the highest scores for any Indian state. As per socio-economic survey reports, MMR, Infant Mortality Rate (IMR) and Total Fertility Rates (TFR) in Assam were the highest in the country. So the primary objective was to bring these indicators down significantly ${ }^{18}$.

The rural population was engaged in farming and cattle-raising. During the floods the river swells and submerges the land; in the process it alters the contours of the islands. The flood brings in epidemics and untold miseries. The people are dependent on the water in the wells which gets contaminated during the floods. Mosquitoes, insects etc were rampant and these posed another set of diseases and problems. Hygiene levels of the people were invariably low.

Immunization programs were naturally given the top priority by the boat-clinic. Family planning services received the next priority which received support from Population Foundation of India. Considering the education and awareness level of the target population family planning services envisaged counseling to a large extent to educate the people and to remove the misconceptions and superstitions. In a short span of time the boat-clinics have been able to bring about a distinct change in the attitude of the population towards immunization programs and the family planning services: awareness has increased; suspicion has decreased. Each boat-clinic timed its visits in sync with the immunization schedule of children as well as the pre-natal and ante-natal check-up of women in its target area.

The task of mobilizing the communities to the camp was undertaken by workers of ASHA (Accredited Social Health Activists) and Village Health \& Sanitation Communities (VHSC). Annual and monthly plans of activities were planned in consultation with the District Health Department to ensure that they do not clash with the immunization schedules. Micro plans were worked out in consultation with the Block PHC (Primary Health Centre). Medicines and vaccines are supplied by Joint Director of Health Service through district drug stores against indent. It was absolutely necessary to achieve close coordination with different govt. departments and district NHRM unit, including the police. Health camps were normally conducted on the banks and adjacent to the boat. During winter when the water receded, boats would not get the draft required to dock near the villages; the team had to trek long distances on foot with loads of equipments and medicines.

People in many of the islands - known as "sapori"s in Assamese - had not seen a doctor nor were familiar with the modern medical systems in their life time. At a health camp in Dhemaji, lower Assam, the health team was elated to know that a child born to one of the women who were under pre-natal supervision of the health team was named "Doctor"! 19.

By the end of 2012 the project had 15 boat-clinics at its command, 235 persons working with dedication and most of the island-villages have been touched. In December 2012 plans have been finalized to have a floating hospital in the River Brahmaputra with financial assistance from North East Council. When Sanjoy Hazarika initiated the project in 2005, his primary objective was to connect the island villages with the outside world and provide them health care in the first place. He had identified many secondary and tertiary objectives which included enhancing livelihood opportunities to the villages, enhancing their skills, providing educational opportunities to the children of the villages etc. These were the new challenges to be tackled from 2012 onwards.

\section{The New Challenges}

\subsection{Organization, Legal Entity}

The concept of boat-clinics was started as an innovative initiative of Sanjoy Hazarika through the vehicle 
of C-NES which found eloquent support from the Government of Assam and a host of others. Over the initial 7 years (from 2005 to 2012) the initiative has proved itself to be the most appropriate solution to the logjam of developmental efforts that plagued the region for more than half-century since independence. The initiative has been implemented as a project in the PPP format; by the end of 2012 it has come to a stage where the project needed to search for and identify its own paradigm of long-term sustainability. In the initial phase the project remained as an off-shoot of C-NES with active involvement of the Government of Assam and teams of dedicated volunteers. At the close of 2012, the project was still not an independent legal entity. This was perfectly justified in the initial phase where hand-holding was absolutely necessary. When the project was beginning to be bestowed with larger roles and responsibilities, it would be prudent to think and debate the constitutional format that the entity should acquire. Should it continue as an extended arm of C-NES? Should it be an extended arm of the Government? Or should it be converted into an independent organizational entity at arms-length from C-NES and the Government of Assam? Should it be allowed to develop its own ethos and culture befitting the task at hand, the technology being employed and the people being served? Should it not emerge as a people's organisation working for people's welfare?

\subsection{Revenue Streams}

The initial phase was characterised by philanthropy and Government funding. Even the thought of generating revenue was not feasible considering the income or rather poverty levels of the people being served to. C-NES had only provided a more effective vehicle to the Government to channelize its health-care budgets. C-NES had leveraged its delivery capability and reputation to raise funds to create the infrastructure and logistics. To sustain the operations in the long-run into the future, would it be prudent to depend exclusively on budgetary grants or depend exclusively on donations? The first option would make it into a government department complete with inherent characteristics. The second option would make the organization and its operations highly volatile and extremely risky. While it may continue to accept budgetary grants from government and donations from individuals and corporate bodies, it would be desirable and necessary to explore primary and secondary streams of revenues. To quote from Bible, a person's hunger can be mitigated by giving him fish to eat; but a sustainable solution would be teaching him how to fish.

Given the socio-economic conditions of the "sapori"s in 2012, the scope for charging the beneficiaries (primary source of revenue) for the services rendered was minimal or absent. It would be necessary to explore innovative methods of pricing in future, based on the socio-economic conditions of individual households; this would lend a sense of ownership among them.

C-NES had earlier received interests from insurance companies to provide health insurance to the target group at an annual premium of Rs. 130 per adult. Apparently this proposal had not materialized. This is an idea worth exploring with fair amount of customization. For instance the insurance coverage should be based on the family or house-hold rather than individual adult as a unit. Since the families were too poor to pay the premium initially, the insurance coverage of a village or a cluster could be bundled together and some corporate houses could be persuaded to bear it. As the socio-economic conditions improved the families should be made to take a share of the premium, gradually increasing their shares over the years.

In the initial proposal Sanjoy Hazarika had mentioned about the prospect of transportation of people and goods as a strong possibility in a riverine state. He had also mentioned about the prospect of using the fleet for tourism, research and documentation etc. These implied services that could be priced leading to sources of secondary revenue. To reap the benefit of secondary revenues the fleet-size has to be large. Separate fleet and personnel must be created for each activity. In such a situation revenues from handling cargo, transporta- 
tion and tourism could be used to cross-subsidize the expenses of healthcare.

\subsection{People Related Issues}

In the initial phase of the project the people working on the project belonged primarily to C-NES and government; many were volunteers from other institutions. All of them were invariably motivated and dedicated to the cause of serving the people. Besides they were thrilled and excited about creating a new path in providing healthcare in Assam. What enabled them to face the hardships and challenges were their dedication, the excitement of creating a new path and the leadership provided by Sanjoy Hazarika. These factors stood them in good stead in building up a cohesive team despite the different backgrounds and working habits of the people who got together. If boat-clinics have to evolve into an organisation providing the services on a long-term basis, the people manning the organization would need definite grooming and induction; the organization would need to address the employees' working conditions, training needs, growth prospects, long-term career aspirations etc. These aspects demand special attention because the work timings and conditions would be highly demanding.

The boat-clinic organization would have tremendous challenges in documentation: the profile of the target audience, the nature of their ailments, the seasonal variations etc are bound to offer a whole range of challenges. The organization would need to create good amount of knowledge management processes besides robust HR processes to ensure long-term sustainability and continued success.

The evolving organization will be a grass-root organization interacting continuously with variety of people. To be able to operate continuously it would have to be acceptable to all its target group without any bias of caste, class, religion or ethnic nature. It would need to be apolitical at all times; it cannot afford to be hijacked by any political party/ grouping however big it may be. These would be the challenges of continuous nature at all levels. The people at levels of the organization would need robust training to face these challenges. The organization should groom leaders from within; only then can it hope to remain alive in the long-run.

\subsection{Tail Piece}

The Brahmaputra valley calls for a robust organization providing healthcare and many other services to develop the people who have been unconnected with the rest of the world for so long. Sanjoy Hazarika, C-NES and the pilot project, Ship of Hope, have come up with a solution. The emerging organization would have to address the myriad challenges on its own terms with its own genius. Vaghese Kurien and the villagers of Kheda district in Gujarat, India created AMUL as a cooperative venture and marched towards prosperity $^{20}$. Prof. Mohammad Yunus and the have-nots of Bangladesh created Grameen Bank, lent themselves the dignity of existence and redefined the concept of micro-finance ${ }^{21}$. Both were inspired by poverty alleviation and neither of them were non-profits. In fact Mohammad Yunus proclaimed that charity is not a solution for poverty and built this philosophy into the structure of Grameen bank. The model and structure that the boat-clinic would take in its forward march in the years to come would be something the developing world would wait to see, anxiously.

Professor P.Bala Bhaskaran prepared this case as the basis for class discussion rather than to illustrate effective or ineffective handling of an administrative situation.

The author is highly indebted to Dr Sanjoy Hazarika, the Managing Trustee of C-NES and Ms Bhaswati Goswami, Communications Officer, C-NES, North East Campus for providing vital information regarding the operations of the initiative.

As part of the narration of the case, if any opinion, suggestion, alternative model is explored and discussed, it is purely with the intention of exploring alternative models of managing similar situations in the future; they have nothing to do with the current policies and plans of C-NES or its affiliates. 


\section{End Notes}

1. Maijan Ghat refers to the river-port on River Brahmaputra in the district town of Dibrugarh.

2. 'Akha' means hope in Assamese language; the equivalent word in most other Indian languages is 'Asha'.

3. Kamal Gurung, the boat mechanic.

4. 'Dholla' is a town on the banks of River Brahmaputra famous for its traditional boat-makers and their workshops.

5. 'Dhoop' in most Indian languages means incense sticks. Lighting incense sticks is considered auspicious.

6. Ship of Hope: Hope Floats! Email from Sanjoy Hazarika, April 26, 2005. http:1//ne.aidindia.org/ Publicity/HopeFloats.pdf

7. Brahmaputra River.http://en.wikipedia.org/wiki/ Brahmaputra_River

See this document for river-dependant assets and situations of flooding etc.

8. Jeffrey Sachs in his book, "End of Poverty" has described about the differential rates of development of societies due to inherent geographical reasons thus leading to significant differences in economic development over a prolonged period of time. He makes special mention about land-locked societies, are more likely than not lag far behind island and/or peninsular societies.

$9 \& 10$. Sanjoy Hazarika, in his initial proposal to World Bank had envisaged the boats to be vehicles for social and economic development. This can be seen in the World Bank Proposal.

11.'Panchayat' refers to village council which debates and decides on the affairs of the village. Traditionally it consisted of village elders. Lately they are all elected by the residents of the village through a systematic electoral process.

12.'Haat' and 'Ghat' culture. Haat refers to the village market which generally happens only once a week. The vendors converge in a given village on a prespecified day of the week for the convenience of a cluster of villages. These vendors travel to another location next day to provide the same services for another cluster of villages at another pre-specified location. Ghat refers to the river-port. In riverdependant regions like Assam many of the 'haats' happen at the 'ghat' and the vendors move themselves and their merchandise through the rivers or waterways.

13.Dholla in Tinsukia district was traditionally known for its boat-builders, craftsmen and their workshops. While initiating the Ship of Hope Sanjoy Hazarika took pains to take the designs of the traditional boat-builders for review and improvements by the MIT design team at Cambridge, Massachusetts, USA consisting of Dinesh Balachandran and Anand Sivaraman as also by an independent hydro-engineering consultant, Hari Nair of Cambridge, USA. These are acknowledged in the message of Sanjoy Hazarika (June 2004), after the C-NES proposal was selected for the World Bank award.

14. Since the project envisaged at least one boat for every one of the 13 districts to cover major portion for the target population and since the funds were scarce, it was considered appropriate to raise funds from anyone who could provide. The proposal that went to World Bank envisaged the sources as corporate and individual donors.

15.The optimum size, internal space, layout etc were based on the types of services that a boat-clinic was intended to provide. These are described in a document of C-NES given by Bhaswati K Goswami, Chief Communications Officer, C-NES. These specifications also are reflected in many of the newspaper stories also.

16.By 2012, C-NES had 15 boat-clinics. This is mentioned in the report of Swaminathan S. Ankaleswaria Aiyar in his column 'Swaminomics' (18-9-2011), in the report of Azeera Rahman (19-2-2013) and also in the document given by Bhaswati K Goswami.

17.The high levels of Maternal Mortality Rates (MMR) and Infantile Mortality Rates (IMR) and the context of these are explained in the document given by Bhaswati K Goswami and also reported by Azeera Rahman (19.2.13). 
18.Please see the report of Azeera Rahman (19.2.13) and also the C-NES document authored by Bhaswati K Goswami.

19.In many of the islands, the people had never seen or known a doctor, a stethoscope or syringe. For them a doctor was nothing less than divine. This incident was reported in the news-story of Azeera Rehman (19 February 2013): 'Hope Floats: Assam's Boat Clinics Help Women Plan Families.'http://www. thebetterindia.com/6801/hope-floata-assma-boatclinics-help-women-plan-families/

20.Anand Pattern (also known as Amul Model) is a three-tier cooperative structure. At the bottom tier is the milk-farmers and the Dairy Cooperative Society, formed by the milk-farmers at the village level. The milk-farmers produce the milk; the dairy cooperative society procures the milk and dispatches to the District Milk Union to which the dairy cooperative society is affiliated. The dairy cooperative society pays the milk-famers for the milk procured, measured in terms of quantity and quality; it also facilitates other support services required by the milk-farmers in managing their milk-production efficiently. The second tier consists of district milk unions, which process the milk to facilitate marketing of milk and milk products of higher values. Such district level cooperatives have federated into Gujarat Cooperative Milk Marketing Federation Ltd.(GCMMF), which owns the 'AMUL' brand and markets the milk and milk-products far and wide. GCMMF is the third tier of the structure of Anand Model. The dairy cooperative movement of Gujarat, started in 1946 under the leadership of Dr Varghese Kurien, has created a network of 3.1 million milk-farmers and the millions of consumers in India. $70 \%$ of the milk-producers were small, marginal farmers and landless labourers and included sizeable segment of scheduled castes and tribes. By 2011, the average milk collection per day was 9.1 million litres and they were processed in 30 dairy plants. The largest among these dairy plants was located at Gandhinagar - Mother Dairy - with state- of-the-art facility to handle 3 million litres of milk per day and produce 160 metric ton of milk powder. In 2010-11, GCMMF recoded a turnover of Rs 97.7 billion (US\$ 1.7 billion)

See George, Shanti (1985): Operation Flood-An Appraisal of Current Indian Dairy Policy, Oxford University Press,Delhi. ISBN:978-0-19-561679-8. Heredia, Ruth (1997): The Amul India Story, Tata McGraw Hill, New Delhi. ISBN: 978-0-07-4631607. Also seehttp://amul.com/m/organisation

21.In 1976, Prof Mohamed Yunus, a Full bright Scholar at Vanderbilt University and Professor at Chittagong University, Bangladesh, started a research project to examine the design of a credit delivery system for the rural poor. In 1983 the activities of this project was organized, through government legislation, into a separate entity called Grameen Bank. The basic philosophy with which Prof Yunus started the project was that charity was not a solution to poverty. What started in 1976 as a self-help-group, had emerged into a bank for the poor managed by the poor. By 2006 it had 2100 branches spread over 80,257 villages of Bangladesh with 24,700 employees. Till then it had lent small loans aggregating to US\$ 6.56 billion and had recovered US\$ 5.87 billion. The recovery rate was never less than $96 \%$. In 2006 Prof Mohammed Yunus and Grameen Bank were awarded the Nobel Prize for their "efforts to create economic and social development from below". For more details please see Bernstein, David(2005): The Prize of a Dream - The Story of Grameen Bank, Oxford University Press, New York. ISBN: 0-19-518749-0.

\section{References}

1. Akha - The Ship of Hope http://ne.aidindia.org/SOH/ SOHDocs/5ShipofHopeToday.pdf

2. Sachs, Jeffrey (2005): End of Poverty, Penguin Books, New York.

3. The proposal (that went into the World Bank Development Marketplace and made it to the finals - 50 out of 1500 proposals) by Center for North East Studies, New Delhi. 
http://ne.aidindia.org/SOH/SOHDocs/1PhaseIproposal. pdf

4. The Ship of Hope Proposal: http://ne.aidindia.org/ Publicity/ShipOfHope.pdf

5. Victory: Ship of Hope wins the World Bank Development Country Level Innovation award! June 2004. http:// ne.aidindia.org/SOH/SOHDocs/3CNESwinstheaward. pdf

6. Report by SanjoyHazarika: One-day health camp at CharkholiaSaporiorganised by C-NES in Association with Dibrugarh District Administration; Date: 10 September 2005. http://ne.aidindia.org/SOH/ SOHDocs/7HealthCamp_AKHA_Sept2005.pdf

7. Pandey, Vineeta (2009): Hope Floats in Marooned villages of Assam; DNA, Dibrugarh; 20 August 2009. http://www.dnaindia.com/india/report_hope-floats-inmarooned-villages-of-assam_1283830

8. Shillong Times (2012): Assam's Boat clinics deliver health services and hope. 12 July 2012. http://www. theshillongtimes.com/2012/07/12/assams-boat-clinicsdeliver-health-services-and-hope/

9. Rehman, AzeeraParveen (2013): Hope Floats: Assam's Boat Clinics Help Women Plan Families. February 19, 2013. Women's Feature Services(WFS). http://www. thebetterindia.com/6801/hope-floats-assams-boat-clinics-help-women-plan-families/

10. Raj, Anand (2012): Ship of Hope; Friday Magazine, Gulf News, November 28, 2012. http://gulfnews.com/ life-style/general/ship-of-hope-1.1111401

11. Aiyar, Swaminathan S Anklesaria (2011): Ships of Hope on the mighty Brahmaputra; The times of India Sep 18, 2011. http://swaminomics.org/?p=2051

12. Hazarika, Sanjoy (2008): Think Innovatively, Plan Realistically and Govern with Participation; ASCI Journal of Management, Administrative Staff College of India, 37(2): 71-77 http://journal.asci.org.in/Vol.37\%28200708\%29/37_2_2008_SANJOY\%20HAZARIKA.pdf 


\section{Box-1: Sanjoy Hazarika}

Sanjoy Hazarika, the managing Trustee of C-NES, is a journalist by profession; he is also a writer, moviemaker and social worker. He was born in Shillong and did his schooling at St. Edmonds School, Shillong; He studied journalism and printing in London.

Sanjoy Hazarika was reporter, South Asia Bureau of New York Times operating out of South Asia during 1981 to 1996 . He had covered the conflicts in Afghanistan, Sri Lanka, Punjab and Kashmir; demise of monarchy and the travails of democracy in Nepal as well as the agony of the North o East of India. He has also captured the economic surge that India experienced in the post-liberalization era. He has directed and produced documentaries and television films which included a series on river Brahmaputra called the River Sutra. He has published five books namely, Bhopal, Lessons of a Tragedy (1988), Strangers of the Mist: Tales of War and Peace from India's North East (1994), Regeneration of India (1995), Rites of Passage: Border Crossings, Imagined Homelands, India's east and Bangladesh (2003) and Writings on the Wall: Reflections on the North East (2008).

He is a Visiting Professor at Centre for Policy Research, a think-tank at New Delhi. He is Consulting Editor of The Statesman, where his column,' the NE Page' appears every Saturday.

His writings formed a major portion of The Times nomination for Pulitzer Prize in 1984. In 2010, his innovative work with the boat clinic won him the Dr Jean Meyer Award for Global Citizenship, Tufts University. He was also awarded the SP Barooah National Award for Journalism in 2001.

\section{Box-2: History of acquisition of the boat- clinics}

The first boat-clinic was commissioned in 2005 in the district of Dibrugarh. This was created out of the grant received from World Bank. Between 2007 and 2009, Swaminathan S Anklesaria Aiyer, the noted journalist, donated funds for acquisition of five boat-clinics. These boat-clinics are attached to the districts of Dhemaji, Dhubri and Tinsukia. Oil India contributed funds for acquisition of a boat-clinic in 2009 which is operating in the district of Jorhat. The boat-clinic acquired through the support of Numaligarh Refinery Ltd in 2010 , is operating in the district of Sonitpur. In all there are 15 boats in operation spread across 13 districts.

\section{Box-3: Partners-Donors}

http://www.c-nes.org/partners-donors

1. UNICEF: Ships of hope, Dibrugarh District, Assam

2. Dibrugarh District administration, Government of Assam (ships of hope)

3. Department of Health, Government of Assam

4. National Rural Health Mission (NRHM), Government of Assam

5. Jalan Industries, Dibrugarh, Assam (administrative and logistics support)

6. North Eastern Council: support for the NER Peoples' Vision 2020 document 2005-06 (including a survey of 40,000 households in eight states, the largest in the region) and Colloquium on the North-east, 2004)

7. Sir Dorabji Tata Trust: funded a three-year project Livelihoods by the Brahmaputra on dairy farming and boat transport

8. Ford Foundation: support for the project on The Brahmaputra, creating livelihoods, promoting conservation: saving the Gangetic dolphin, eco-tourism and livelihoods; dairy, health and income growth

9. Ministry of Commerce, Government of India: ongoing detailed study on Look East Policy

10. Friedrich Ebert Stiftung: support for workshops in Delhi on the North-east (2004) and seminars/workshops in Assam and Meghalaya on Bangladesh and the North-east (2001 and 2004)

11. Planning Commission, Government of India: support for Review of projects on Augmented Drinking Water Supply schemes for Dimapur (Nagaland) and Aizawl (Mizoram); chapter on Inland water transport and connectivity for the Assam State Development Report 2002

12. Ministry for the Development for the Northeastern Region, Government of India: support for workshops and seminars in 2004-2005 and 2005-2006 on the Northeast and investment opportunities as well as the Look East Policy, Infrastructure needs and Micro-credit 
13. Assam Foundation for North America and individual contributors for CNES-Setu National Media Fellowship 2005

14. Institute for Developing Economies (JETHRO) of the Ministry of Trade, Japan, for the project: Sub-Regional Relations in The Eastern South Asia: with special focus on India's North Eastern Region (published as a book, 2005)

15. Asian Dialogue Society for conduct of seminars, travel and discussions in Nagaland, Assam and Meghalaya in January 2006 and November 2006 New Delhi and Guwahati on connectivity between the North-east and South East Asia

16. Indian Council of Social Science Research: workshop in Bhopal on The North-east (March 2004) and lectures in Shillong, Guwahati and Dibrugarh by Prof. SumitGanguly of Indiana University, Bloomington, US, and Prof. Lisa Cliggett of University of Kentucky, Lexington, US (2005)

17. World Bank (awarded C-NES a national award for the Ship of Hope concept at the India Development
Marketplace in 2004 which kick-started its innovative river-based health program in Assam)

18. Population Foundation of India

19. Irish Aid Henrich Boll Foundation

20. Foundation for Social Transformation (FST)

21. Oil India Ltd.

22. Numaligarh Refinery Ltd.

Box-4. Services rendered by Boat-clinics

\begin{tabular}{lc}
\hline Category of Services rendered & Cumulative Nos. up to 31-3-12 \\
\hline Health camps & 7,803 \\
Health checkups & $6,31,646$ \\
Routine Immunizations & 74,066 \\
Ante Natal Care ANC & 32,779 \\
Pre-Natal Care PNC & 8,116 \\
Vitamin A & 28,112 \\
Special Vaccination & 11,748 \\
CPPI & 6,716 \\
Family Planning Item Distribution & $1,65,445$
\end{tabular}

Box 4. Boat Clinic under NRHM, 15th March 2008 till 31st March 2013

\begin{tabular}{|c|c|c|c|c|c|c|}
\hline Year & 2008-09 & $2009-10$ & 2010-11 & 2011-12 & $2012-13$ & \\
\hline Total Camps & 1005 & 1867 & 2159 & 2772 & 2582 & 10385 \\
\hline Boat Clinic Units & 5 & 10 & $10+5$ & 15 & 15 & 45 \\
\hline Health Checkup & 90932 & 141413 & 174160 & 225141 & 200679 & 832325 \\
\hline RI & 6591 & 20389 & 22269 & 24817 & 21971 & 96037 \\
\hline ANC & 3143 & 6064 & 8893 & 14679 & 11576 & 44355 \\
\hline PNC & 1011 & 1206 & 2400 & 3499 & 3355 & 11471 \\
\hline Vit A & 1879 & 7179 & 7947 & 11037 & 11407 & 39449 \\
\hline Spl.Vaccination & 1574 & 1317 & 2656 & 3608 & 669 & 9824 \\
\hline IPPIP & 4883 & 1672 & 0 & 56 & 708 & 7319 \\
\hline Delivery & 3 & & 0 & 1 & 4 & 8 \\
\hline LS & & & 0 & 240 & 70 & 310 \\
\hline NSV & & & 0 & 7 & 0 & 7 \\
\hline IUCD & & & 0 & 116 & 58 & 174 \\
\hline Total & 110016 & 179240 & 218474 & 285794 & 250493 & 1044017 \\
\hline FP & 3555 & 14030 & 58947 & 88913 & 72068 & 237513 \\
\hline
\end{tabular}




\section{About the author}

Prof. BalaBhaskaran is a management professional and teacher with active interest in the areas of Finance, Entrepreneurship, Business Strategy and Knowledge Management. He is a graduate in technology from Indian Institute of Technology, Madras, India and a post-graduate from Indian Institute of Management, Bangalore, India. He has 18 years of corporate experience in various capacities in India and later has spent 18 years in teaching and institution building. He has published papers and cases in national and international journals; has published four edited books. He has conducted workshops on Case Teaching and Writing for management teachers. He has travelled abroad - USA, Europe, Mid-East and East Asia - in connection with technology selection and educational tie-ups. He is a Non-Executive Director on the board of a set of companies. He is on the Advisory Board of few educational institutions. He is approved as a Mentor by a Venture Capital Company to its start-up ventures. Currently he is a member of the core-team in establishing a biotech incubator near Ahmedabad. He continues to teach management in select institutions; his area of interest covers Business Strategy, Entrepreneurship and Knowledge Management. He can be reached at: bala. bhaskaran@gmail.com. 